\section{Response to 'Everything we see is a perspective, not the truth' by Chattopadhyay et al}

We would like to thank Chattopadhyay et al for their interest in our article presenting the low incident rate of vertebral fractures in an early axial spondyloarthritis (axSpA) population. We have read with interest their comments regarding the external validity of the data we are presenting. ${ }^{12}$

We would like to highlight that the manuscripts the authors are referring to in their letter were focusing only in patients with either very long-standing disease (22.5 years in the Montala study $^{3}$ ) or with radiographic involvement (ie, radiographic axSpA, also referred as ankylosing spondylitis) in both studies. ${ }^{4}$

We would like to emphasise that Devenir des Spondylarthropathies Indifférenciées Récentes (DESIR) is an early axSpA cohorts and to be included, patients could not have axial symptoms for more than 3 years. Furthermore, the presence of radiographic abnormalities was not an inclusion criteria. ${ }^{5}$ Other early onset axSpA cohorts, such as SPondyloArthritis Caught Early (SPACE) or German Spondyloarthritis Inception cohort (GESPIC) have shown comparable populations. Male gender was $46.6 \%$ in the DESIR cohort, $44.6 \%$ in the SPACE cohort ${ }^{6}$ and $51 \%$ patients in the GESPIC cohort, ${ }^{7}$ human leukocyte antigen-B27 was positive in $57.8 \%, 67.7 \%$ and $79.0 \%$ in DESIR, SPACE and GESPIC cohorts, respectively. This phenomenon (early disease presentation being slightly different from long-standing disease) is not unique in axSpA and has also been reported in other diseases such as rheumatoid arthritis (RA). The percentage of anticitrullinated protein antibody (ACPA)-positive patients included in randomised phase III clinical trials with established disease is usually $>75 \%$, whereas the percentage is around $30 \%$ in the early RA cohorts. ${ }^{8}$

Concerning the comment on the diagnostic utility of the low back pain as a criteria for axSpA, we would like also to emphasise that in order to be included in DESIR, patients had to present with inflammatory back pain (and not just low back pain) according to the Calin ${ }^{9}$ or the Berlin ${ }^{10}$ criteria for inflammatory back pain for more than 3 months and less than 3 years. But they also have an axSpA diagnosis confidence $>5 / 10$ according to the rheumatologist. ${ }^{5}$ Furthermore, at inclusion, $92.1 \%$ patients fulfilled at least one classification for axSpA.

Finally, the authors suggest that perhaps our results are different from the literature due to the inclusion of both nonradiographic and radiographic forms of axSpA. This seems difficult to confirm, since in our analysis, the prevalence of vertebral fracture was not different in both groups, but the incidence was so low overall that it could not be tested.

\footnotetext{
Anna Molto $\odot{ }^{1,2}$ Julie Sahuguet, ${ }^{1}$ Jacques Fechtenbaum, ${ }^{1}$

Adrien Etcheto, ${ }^{1}$ Clementina López-Medina, ${ }^{1,2}$ Pascal Richette $\odot{ }^{3}$ Maxime Dougados, ${ }^{1,2,4}$ Christian Roux, ${ }^{1,2,4}$ Karine Briot $\circledast^{1,2}$

1 Department of Rheumatology, Cochin Hospital, Assistance Publique- Hôpitaux de Paris, Paris, France

${ }^{2}$ INSERM U1153, Paris, France

${ }^{3}$ Department of Rheumatology, Lariboisière Hospital, Assistance Publique- Hôpitaux de Paris, Paris, France
}

${ }^{4}$ Paris-Descartes University, Paris, France

Correspondence to Karine Briot, Department of Rheumatology, Cochin Hospital, Assistance Publique- Hôpitaux de Paris, Paris 75014, France; karine. briot@aphp.fr

Handling editor Josef S Smolen

Contributors All the authors contributed equally to the this response.

Funding The authors have not declared a specific grant for this research from any funding agency in the public, commercial or not-for-profit sectors.

Competing interests None declared.

Patient consent Not required.

Provenance and peer review Commissioned; internally peer reviewed.

(c) Author(s) (or their employer(s)) 2020. No commercial re-use. See rights and permissions. Published by BMJ.

\section{Check for updates}

To cite Molto A, Sahuguet J, Fechtenbaum J, et al. Ann Rheum Dis 2020;79:e46.

Received 31 January 2019

Accepted 31 January 2019

Published Online First 13 February 2019

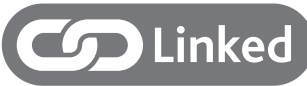

- https://doi.org/10.1136/annrheumdis-2019-215109

Ann Rheum Dis 2020;79:e46. doi:10.1136/annrheumdis-2019-215131

\section{ORCID iDs}

Anna Molto http://orcid.org/0000-0003-2246-1986

Pascal Richette http://orcid.org/0000-0003-2132-4074

Karine Briot http://orcid.org/0000-0002-6238-2601

\section{REFERENCES}

1 Chattopadhyay A, Dhir V, Jain S. Everything we see is a perspective, not the truth. Ann Rheum Dis 2020;79:e46.

2 Sahuguet J, Fechtenbaum J, Molto A, et al. Low incidence of vertebral fractures in early spondyloarthritis: 5-year prospective data of the DESIR cohort. Ann Rheum Dis 2019;78:60-5.

3 Montala N, Juanola X, Collantes E, et al. Prevalence of vertebral fractures by semiautomated morphometry in patients with ankylosing spondylitis. J Rheumatol 2011;38:893-7.

4 Kang K, Kim I, Jung S, et al. Incidence and predictors of morphometric vertebral fractures in patients with ankylosing spondylitis. Arthritis Res Ther 2014;16.

5 Dougados M, Etcheto A, Molto A, et al. Clinical presentation of patients suffering from recent onset chronic inflammatory back pain suggestive of spondyloarthritis: the DESIR cohort. Joint Bone Spine 2015;82:345-51.

6 van den Berg R, de Hooge M, Rudwaleit M, et al. ASAS modification of the Berlin algorithm for diagnosing axial spondyloarthritis: results from the SPondyloArthritis Caught Early (SPACE)-cohort and from the Assessment of SpondyloArthritis international Society (ASAS)-cohort. Ann Rheum Dis 2013;72:1646-53.

7 Rudwaleit M, Haibel H, Baraliakos X, et al. The early disease stage in axial spondylarthritis: results from the German spondyloarthritis inception cohort. Arthritis Rheum 2009;60:717-27.

8 Funovits J, Aletaha D, Bykerk V, et al. The 2010 American College of Rheumatology/ European League against rheumatism classification criteria for rheumatoid arthritis: methodological report phase I. Ann Rheum Dis 2010;69:1589-95.

9 Calin A, Porta J, Fries JF, et al. Clinical history as a screening test for ankylosing spondylitis. JAMA 1977;237:2613-4.

10 Rudwaleit M, Metter A, Listing J, et al. Inflammatory back pain in ankylosing spondylitis: a reassessment of the clinical history for application as classification and diagnostic criteria. Arthritis Rheum 2006;54:569-78. 